\title{
Exploring an Agile Learning Activity to Teach Agile Project Management
}

\author{
Raafat George Saadé, and Syed Shah \\ Concordia University, John Molson School of Business, \\ Montreal, Quebec, Canada \\ raafat.saade@concordia.ca syed.shah9240@gmail.com
}

\begin{abstract}
In this study, we adapted the agile approach to teaching. Students took an idea from inception, through the first and second agile project management iterations, and incorporated feedback from their classmates in between. The goal was to demonstrate through a flexible process how products/services can be improved. We started with the practice and followed up with the theory. The results and metrics were positive in terms of the outcomes that the agile project management approach intends to produce. There was a clear enhancement to the product/service measured value (along 3 metrics) in the second iteration. We describe herein the context, the process, the tool used, and the results and we conclude with a small discussion on the limitations of the study.
\end{abstract}

Keywords: Agile, Project Management, Teaching, Informing.

\section{Introduction}

In the last decade, project management has gained a lot of attention. This is due to the fact that project management makes the promise to control the development (or building, to be more general) of products and services under complex and uncertain conditions. This promise of control gives the expectations that following the project management approach would result in an identifiable outcome of value. The project management approach is seen as a collection of activities that follow unique and complex management processes. To that effect and in consideration of efficiencies, standardization best practices were established to formalize these activities, such as the PMI and PRINCE2 (Dyba \& Dingsoyr, 2015).

Today, not everyone agrees that these standards are a sufficient solution to address the challenges of complex projects (which is the case in most of the times). As a matter of fact, most projects today are managed under fast-changing and highly uncertain environments (Saade et al., 2015). In this case, it is not wise to follow traditional standards which were based from lessons learned from past project, unsuitable for today's fast paced business environment. The greater the uncer-

Material published as part of this publication, either on-line or in print, is copyrighted by the Informing Science Institute.

Permission to make digital or paper copy of part or all of these works for personal or classroom use is granted without fee provided that the copies are not made or distributed for profit or commercial advantage AND that copies 1) bear this notice in full and 2) give the full citation on the first page. It is permissible to abstract these works so long as credit is given. To copy in all other cases or to republish or to post on a server or to redistribute to lists requires specific permission and payment of a fee. Contact Publisher@InformingScience.org to request redistribution permission. tainty in a project, the less the applicability of fixed-sequence based project management approaches, and the more flexibility is required in changing course along the project life cycle. This is a significant and important shift to flexible and interactive project management style where learning and adaptation occurs throughout the project. 
Fortunately, a solution to this problem already existed in the form of agile software development. Agile software development is the name for a number of techniques (Scrum, DSDM, Xtreme, etc...) which fall under the umbrella of agile. Agile development is primarily a philosophy, not a rigorous framework; a way of thinking not a set of steps or procedures. ("Manifesto for Agile Software Development", 2001) This allows agile methodologies to be adapted for use outside of software development.

We saw precisely this phenomenon occurring while working in "District3". District3 is a startup incubator for early stage startups, located in Concordia University, Montreal, Quebec, Canada. It is an open incubator and available as a resource for anyone in the community (students, teachers, staff, companies, associations, etc...), where startup founders can work alongside like-minded individuals, and obtain mentorship from a variety of experienced mentors across a range of areas relevant for startups, a wealth of potential team members and the space and tools to work on their ideas.

While teaching a final year project management class in a business technology management program in a business school, we decided to integrate the Agile project management approach. Although the course was axed around the Project Management Institute knowledge areas and processes, with some treatment of PRINCE2, we found value in exploring the addition of the agile project management approach into the pedagogy.

In order to teach agile project management, it is important to define agile project management. In summary, the key socio-technical principles of agile project management (APM) include minimum critical specifications, autonomous teams, redundancy, and feedback and learning (Dyba \& Dingsoyr, 2015). Serrador \& Pinto (2015), provide an in-depth literature review of agile/iterative project management methods and present in their article the question: Does Agile Work?

In the co-authors personal experience at D3, two important aspects of agile project management are; time boxing and iterative development both of which are discussed by Moran, A. (2015), in his book Managing Agile, and which are often talked about when it comes to agile project management. What is less talked about, but is just as important, if not more important is the values behind agile project management. At D3, the lean principles of respect for people and continuous improvement are stressed heavily alongside more mechanical aspects such as time boxing and iterative development, and which contribute heavily to the success of teams. The focus on people is central to agile project management but is something that is often forgotten.

As for the success of Agile Project Management, Serrador \& Pinto (2015) have done an extensive qualitative analysis in this area, having analyzed nearly 1400 projects, and concluded that agile methods have a positive impact on project success. The caveat being that the quality of project vision and goals in terms of alignment with overall strategic goals was found to be marginally significant as a moderator of this impact.

In the present study, we investigated an agile approach to teach agile project management. This decision was made after our experience with District 3 . It seemed only natural, especially given that the agile method is gaining grounds in industry, and therefore is important to consider its place in the information systems (IS) curriculum (Landry \& McDaniel, 2015).

\section{Methodology}

\section{Approach}

The approach taken to teaching agile was to actually follow the agile approach as a pedagogical process (an activity based approach). The activity chosen was focused on iterative development, time boxing, and stressed the importance of learning (through feedback and testing), with as little 
specifications provided as possible. These were some of the most important aspects of APM and provided enough of a foundation from which there could then be a follow up discussion on agile.

\section{Process}

The class was initially divided into groups of 3-5 students. These students were then given the task of coming up with a product or service for their peers. Their peers would then score (out of 10, 10 being very likely) them on 3 main criteria (explained at the end of this section); How likely are you to a) use this product, b) recommend this product, c) pay for this product.

The teams then had to describe an initial idea (see analysis and results), with only a very basic knowledge of the market (their peers in the classroom.) They were then tasked with going through their peers' products/services and rating them based on the aforementioned criteria.

The teams were then tasked with going back and coming up with a set of questions in order to obtain more feedback. This allows the team to react to the feedback given to them based on the basic criteria, and then develop where they would like feedback.

Finally, teams are then told to respond to the questions created by the other teams in order to fulfill the feedback requirement. The teams may are then to complete their second iteration of their product or service and this iteration is then reassessed by their peers based on the same 3 criteria initially assessed.

\section{Analysis \& Discussion of Results}

In Table 1, we see the description of the product/services that the teams produced. That there was no correlation between the description and the rating raises some interesting points of discussion. For example, the complexity of the idea, or the depth of the description does not have an obvious connection to the quality as determined by the market. What then would determine it? Is the obvious follow up question. To determine any answer is not reasonable given the data set, but leaves interesting room for follow up research, or follow up iterations of the activity to explore.

Table 1: Product description of participating groups.

\begin{tabular}{|c|c|l|}
\hline \multicolumn{2}{|l|}{$\begin{array}{l}\text { Gro } \\
\text { up }\end{array}$} & $\begin{array}{l}\text { Product } \\
\text { Title }\end{array}$ \\
\hline A & $\begin{array}{l}\text { Product Description } \\
\text { Quick Sip }\end{array}$ & $\begin{array}{l}\text { The Quick Sip is an ergonomic, stylish, and lightweight coffee mug. The benefits of } \\
\text { this mug compared to every other one currently on the market is that burns are } \\
\text { avoided, drinking waiting time is diminished, ergonomically designed, and a vacuum } \\
\text { sealed insulation is provided. The way this mug works is that it is designed to keep } \\
\text { the coffee heated until ready to be sipped by the individual. The mug has two cham- } \\
\text { bers, one that keeps the drink hot for hours while the second chamber is made from } \\
\text { different metals which will wick away the heat. On top of the mug the lid will have a } \\
\text { button which when pressed will release a small amount of the fluid into a secondary } \\
\text { chamber found at the top of the mug. This chamber helps to rapidly cool the fluid in } \\
\text { order for it to be at an adequate drinkable temperature. The price is 25\$ to compete } \\
\text { with other high end thermo mugs. }\end{array}$ \\
\hline B & $\begin{array}{l}\text { PieceofPie is a crowd-investing (CI) online interface, where individual investors can } \\
\text { acquire a share of a project in exchange of capital. PieceofPie will take a small per- } \\
\text { centage of the capital used to finance the project. Compared to Kickstarter, } \\
\text { PieceofPie gives investors the opportunity to own part of the project. There are two } \\
\text { types of contributors to the CI interface, including: the investor and the entrepreneur. } \\
\text { An entrepreneur can present his idea (business plan) on the platform, with the objec- } \\
\text { tive to attract investors for a specific required capital. On the other hand, an investor } \\
\text { can invest in ideas in a unique fashion (phone application, website...) and receive } \\
\text { shares. }\end{array}$ \\
\hline
\end{tabular}




\begin{tabular}{|c|c|c|}
\hline $\mathrm{C}$ & $\begin{array}{l}\text { OPUS } \\
\text { card App }\end{array}$ & $\begin{array}{l}\text { A NFC based Smartphone App that will enable STM rides like an OPUS card but } \\
\text { without the Card ;) }\end{array}$ \\
\hline D & $\begin{array}{l}\text { Tinder for } \\
\text { Apart- } \\
\text { ments }\end{array}$ & $\begin{array}{l}\text { - A mobile app for discovering potential apartments. } \\
\text { - Swipe right for interested and chat with the landlord } \\
\text { - Swipe left for not interested } \\
\text { - Seeker/User profile information will include: location preferences, pet friend- } \\
\text { ly, number of bedrooms/bathrooms, furnished or unfurnished option, Wi-Fi \& } \\
\text { utilities option. }\end{array}$ \\
\hline $\mathrm{E}$ & $\begin{array}{l}\text { All-in-one } \\
\text { Access } \\
\text { Card }\end{array}$ & $\begin{array}{l}\text { Our product will be an "all-in-one" access card that allows the customer to link all } \\
\text { their magnetic card (VISA, Mastercard, AMEX, Gift Cards, STM Opus, ID } \\
\text { cards). } \\
\text { - The product will be secured by the customers' fingerprint and PIN number. } \\
\text { - Only credit products will be eligible for the flash pass (pay pass). } \\
\text { - Opus card will be replaced by this physical card. } \\
\text { - Cards can be automatically linked via a laptop or computer. } \\
\text { - The card will have a LCD screen that will display IDs (ex. Student } \\
\text { ID/Drivers' Licence/Health Insurance) }\end{array}$ \\
\hline $\mathrm{F}$ & $\begin{array}{l}\text { Kugg-e } \\
\text { (Ket- } \\
\text { tle+Mug+ } \\
\text { Electron- } \\
\quad \text { ics }\end{array}$ & $\begin{array}{l}\text { A mug with a re-chargeable base that serves as a boiler for the liquid inside for hot } \\
\text { tea on the go! } \\
\text { Features include... } \\
\text { - Buttons on the exterior of the mug, you will be able to increase or maintain } \\
\text { the temperature inside. } \\
\text { - The base will also be able to charge your electronics via a USB port. (One } \\
\text { port with a variable switch to control electricity flow) } \\
\text { - Screw on auto-seal spill-proof cap } \\
\text { - Expansion pack: Bluetooth compatible for built-in mobile speaker, lid for } \\
\text { loose leaf tea, energy efficient LED lights built-in to bottom for flashlight use } \\
\text { purposes }\end{array}$ \\
\hline $\mathrm{G}$ & $\begin{array}{l}\text { Parking } \\
\text { Infor- } \\
\text { mation } \\
\text { App }\end{array}$ & $\begin{array}{l}\text { We are planning on creating a phone app that will tell you, depending on where you } \\
\text { are parked in montreal (or where you plan on parking) the allowed hours and infor- } \\
\text { mation about the parking spot restrictions. For instance, the app will show a over- } \\
\text { head map, and highlight the various restrictions ( payed parking, time restrictions or } \\
\text { if you are even allowed to park there at all !). This app will remove any worries for } \\
\text { people who are unsure whether they are permitted to park somewhere, especially in } \\
\text { places with multiple parking signs. This will save consumers time, and minimize } \\
\text { drivers risk and ultimately save them money on parking tickets. }\end{array}$ \\
\hline
\end{tabular}

The results were extremely positive in terms of demonstrating the benefits of agile first hand. In almost every group there was a significant increase in the average score from iteration 1 to iteration 2 (see Figure 1). 


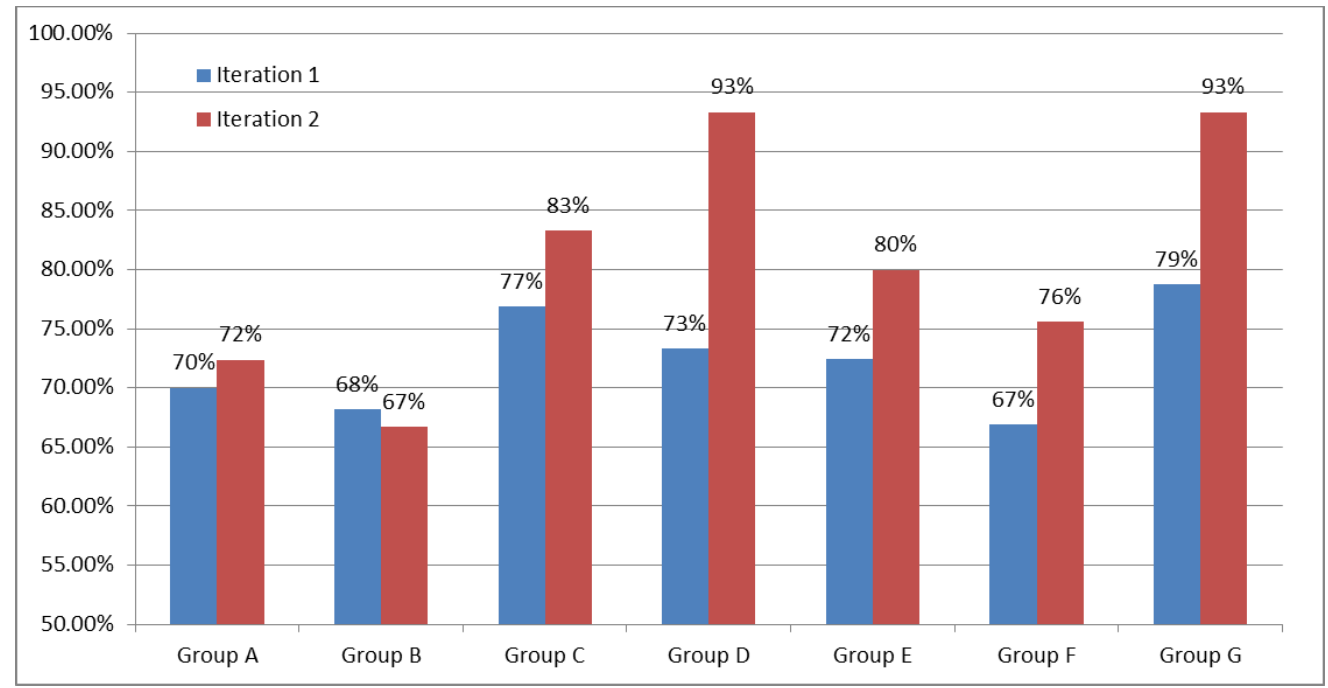

Figure 1: Product/Service Score for iteration 1 and 2

The percentage increase between iteration 1 and 2 was also quite significant, going into double digits for most of the projects (see figure 2).

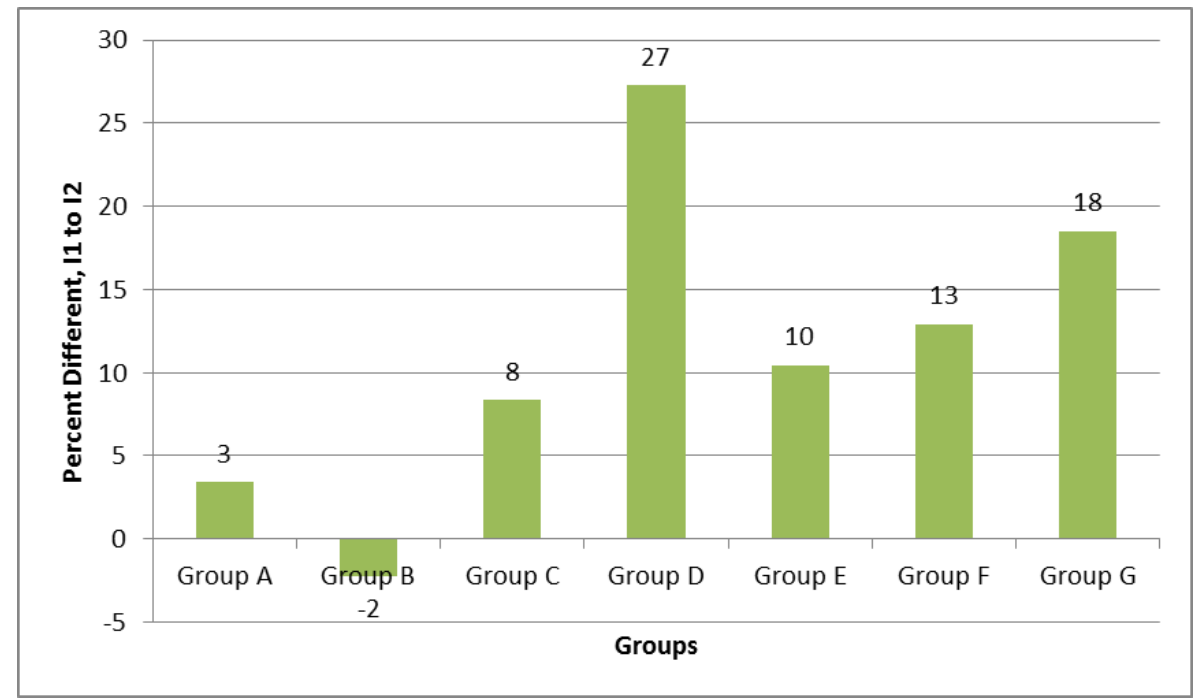

Figure 2: Percent difference in score from iteration 1 to iteration 2

Figures 1 and 2 indicate that the process executed in a guided way produces the desired results expected from the APM. At the end of the second iteration, a discussion would ensue on their experience and then their experiences explained in terms of the APM elements such as time boxing. The impact of the agile pedagogy for teaching seems to be effective. 


\section{Conclusion}

In conclusion, we took an agile practice to teaching agile project management in a university classroom setting. Students took an idea from inception, through the first and second iterations, and incorporated feedback from their classmates in between the first and second iteration. They were provided with some overarching guidelines in terms of moving between the steps and for incorporating feedback in between iterations. The rest was up to the students to determine for themselves, in accordance with the philosophy of being agile.

The results and metrics were positive in terms of the outcomes that the APM approach intends to produce. The average score between iteration 1 and iteration 2 was fairly drastic and did a good job of demonstrating agile project management and the immediate impact it can have. In virtually every case, the score improved from the $1^{\text {st }}$ iteration to the $2^{\text {nd }}$, and in most cases, improved significantly (double digit percentage.)

The caveat being that the number of respondents that determined the score decreased drastically from iteration 1 to iteration 2. This was most likely due to the timing of the class during which this activity took place; it was late in the evening and went over schedule. The tool used for this activity, provided by a third party (Learning Campus) while fulfilling what was required, was not an idea tool. However, Learning Campus has agreed to develop a tool specifically for activities such as this, and in doing so, open up the possibility of conducting the activity on a larger scale. With the new tool, it should be simple and straightforward to conduct this activity entirely online, which brings with it the possibility of much larger sample sizes, as the number of students can increase. Also, as this activity will be done online, time is no longer an issue, as the iterations can be completed at student's leisure.

The limitation however, was that the number of respondents from iteration 1 to iteration 2 was significantly less (see table 2). This was most likely due to the timing, as the class was an evening class, and with discussions and explanations, the activity went longer than anticipated.

Table 2: An example of a table

\begin{tabular}{|c|c|c|}
\hline Group & No. of respondents I1 & No. of respondents I2 \\
\hline A & 28 & 7 \\
\hline B & 26 & 7 \\
\hline C & 28 & 4 \\
\hline D & 25 & 5 \\
\hline E & 30 & 2 \\
\hline F & 27 & 3 \\
\hline G & 27 & 2 \\
\hline
\end{tabular}

With the development of a specialized tool by Learning Campus, this limitation could be entirely overcome. With the activity taking place online, class time wouldn't factor in, and the number of respondents and the number of iterations could both increase. 


\section{References}

Dyba, T., \& Dingsoyr, T. (2015, May). Agile project management: From self-managing teams to largescale development. In Software Engineering (ICSE), 2015 IEEE/ACM 37th IEEE International Conference on (Vol. 2, pp. 945-946). IEEE.

Saadé, R. G., Dong, H., \& Wan, J. (2015). Factors of project manager success. Interdisciplinary Journal of Information, Knowledge, and Management, 10, 63-80. Available at http://www.informingscience.org/Publications/2265

Landry, J. P., \& McDaniel, R. (2015). Agile preparation within a traditional project management course. In Proceedings of the EDSIG Conference (p. n3429).

Manifesto for Agile Software Development. (n.d.). Retrieved March 24, 2016, from http://www.agilemanifesto.org/

Moran, A. (2015). Agile project management. In A. Moran, Managing agile: Strategy, implementation, organisation and people. Springer.

History: The Agile Manifesto. (n.d.). Retrieved March 24, 2016, from http://agilemanifesto.org/history.html

Serrador, P., \& Pinto, J. K. (2015). Does Agile work?-A quantitative analysis of agile project success. International Journal of Project Management, 33(5), 1040-1051.

\section{Biographies}

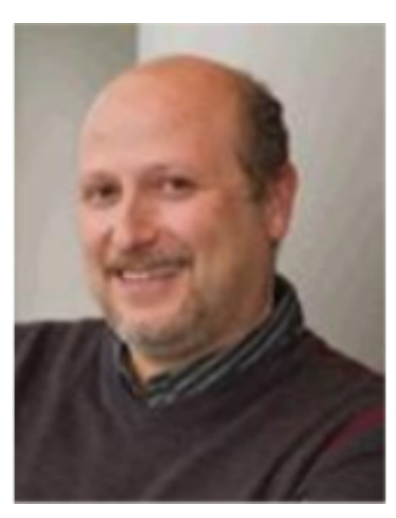

Dr. Raafat George Saadé has been teaching in JMSB since 1998. He obtained his PhD in 1995 (Concordia University) after which he received the Canadian National Research Council (NSERC) postdoctoral fellowship, which he completed at McGill University in Montreal. Dr. Saadé has extensive industry experience: research project manager, product developer and supply chain manager, operations manager, project leader, and information systems designer. Since 2000, he was also a consultant to the Canadian International Development Agency (CIDA) providing advice on international projects in Ukraine, Pakistan, and Slovenia. In the past 3 years, Dr. Saadé has been a senior advisor at the International Civil Aviation Organization (ICAO) providing input on strategic planning for organizational change. Dr. Saadé has published in top tier journals such as Information \& Management, Decision Sciences, Education and Computers, Decision Support Systems, Computers and Behavior, Journal of Information Technology in Education, and Expert Systems with Applications.

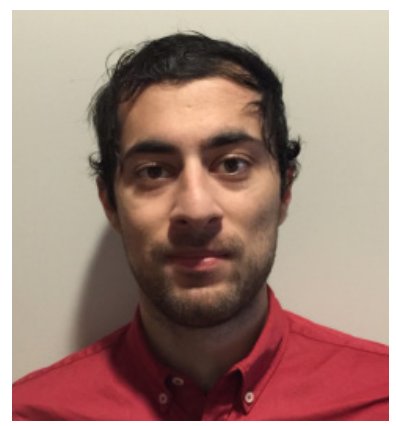

Syed Shah is a graduate from the Supply Chain and Business Technology Management, at the John Molson School of Business in Concordia University, Montreal, Quebec, Canada. He has been a Teaching and Research Assistant for over two years engaged in a number of activities including but not limited to project management, ERP/SAP, Innovation, and data analysis. His main areas of interest include entrepreneurship and agile project management. 